\title{
Microbiological assessment of food crops irrigated with domestic greywater
}

\author{
Siobhan Jackson ${ }^{1,2 *}, \mathrm{~N}$ Rodda $^{2}$ and L Salukazana ${ }^{2}$ \\ ${ }^{1}$ Durban Metro Water Services, Wastewater Management Laboratory, PO Box 1038, Durban 4000, South Africa \\ ${ }^{2}$ Pollution Research Group, University of KwaZulu-Natal, Howard College, Durban 4041, South Africa
}

\begin{abstract}
Two of the challenges facing Africa in the $21^{\text {st }}$ century are effective use of restricted water resources and ensuring food security. The eThekwini Municipality is not exempt from these challenges and is investigating ways in which they can be addressed in the local context. One of the aims of national government has been to ensure the supply of clean drinking water and suitable sanitation to every household. As part of its efforts in this regard, eThekwini Municipality has introduced a multi-tiered water supply programme ranging from full-pressure water systems and flush toilets to stand pipes and dry toilets. In the dry sanitation systems, there is no real provision for the disposal of domestic greywater and, bearing in mind that South Africa is a water scarce country, the municipality is investigating ways of using this water as a resource rather than viewing it as a waste. A preliminary trial was set up in 2003 using this water to irrigate vegetables to be used for home consumption. The microbiological safety of this practice needed to be examined to ensure that it would indeed help to uplift communities by the provision of healthy food as well as provide an ecologically sound use and reuse of available water.

The initial proposal was to investigate total coliforms, E. coli and Enterococcus as the normal faecal indicators for health purposes as well as Staphylococcus as a human skin surface micro-organism and coliphage as a viral indicator. The first controlled field trial was put in at the test site at the University of KwaZulu-Natal in 2005 using several crop types and three irrigation regimes. The vegetable samples were examined both internally and externally for the selected micro-organisms. It was found that very few $E$. coli were detected and in later crops the micro-organism list was expanded and further identification of the total coliform organisms detected is being addressed. This paper presents the results from the analyses to date.
\end{abstract}

Keywords: greywater, irrigation, health risk, domestic crops

\section{Introduction}

A previous Minister of Water Affairs and Forestry expressed the wish for water in South Africa that there would be 'Some for all, forever'. As the Southern African region is recognised as a water scarce area, action needs to be taken to ensure that this wish is fulfilled. As a leader in the water supply arena in this country, the eThekwini Municipality was the first to implement the concept of $6 \mathrm{k} \ell$ of free water per household per month. At the earliest stages of implementation of community upliftment, the feeling in the communities was that one of their highest priorities was to receive potable water; the aspect of sanitation came much further down on the list. This led to the situation where communities were receiving water but had no formal means of disposing of it after use. In many instances, water was thrown outside the door of the residence resulting in pooling and unsanitary conditions including the breeding of mosquitoes. In any sanitary intervention the Bellagio Principles (Hurst, 2002) need to be kept in mind to ensure acceptability and sustainability of the intervention. In addition, KwaZulu-Natal has the highest HIV positive rate in the country and the eThekwini area is certainly not exempt. In many cases, the family bread winner is either dead or dying, households are headed by children or aged grandparents and finances are

This paper was originally presented at the 2006 Water Institute of South Africa (WISA) Biennial Conference, Durban, South Africa, 21-25 May 2006.

* To whom all correspondence should be addressed.

兽+2731 311-8015; fax:+2731 311-8003;

e-mail: siobhanj@dmws.durban.gov.za at a sub-economic level. As a result, the nutritional status of the household can be extremely poor which results in increased susceptibility to disease and a further drain on resources. An opportunity was seen for the re-use of greywater which could result in an improvement in the living conditions of these families. In 2003, a preliminary trial was set up using greywater to irrigate above-ground vegetables to be used for home consumption. The crops produced appeared to be excellent and the community involved wanted to expand operations. There was some doubt, however, about the hygiene of crops grown under such conditions and whether there needed to be some restriction in the type of crop grown. A joint project between eThekwini Water and Sanitation and the University of KwaZulu-Natal was initiated to investigate these issues.

\section{Experimental design}

A semi-field trial plot was established at the University of KwaZulu-Natal in which it was originally planned that four crops would be planted. During the course of the year additional vegetables were added and the final selection was: spinach, green peppers, madumbis, potatoes, onions, beetroot and carrots. These were grown in plastic bags filled with sterile, low nutrient Berea red sand and drip-irrigated through a plastic bottle with either normal municipal tap water, greywater or a hydroponics solution.

Irrigation through plastic bottles pierced at the bottom was to prevent splash back contamination of above surface growth as far as possible. The vegetables were watered daily with $500 \mathrm{~m} \ell$ of the relevant solution and harvested at maturity, after approximately three to four months. A rep- 


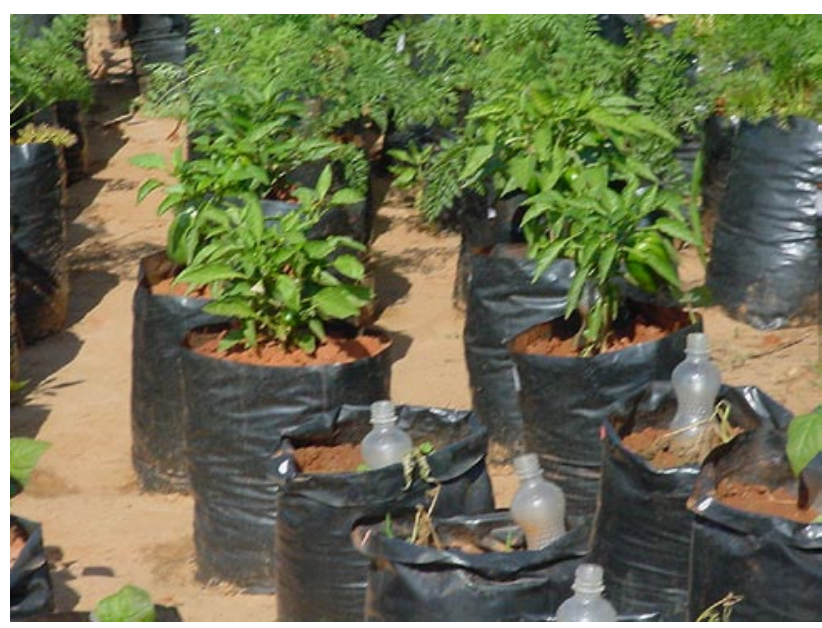

Figure 1

Carrots and green peppers in trial bags irrigated through plastic bottles with greywater, tap water or hydroponics solution

resentative sample of each crop was dried, the percentage dry mass of each sample was calculated and used to calculate bacterial load per dry mass. Fresh samples were weighed and placed in $100 \mathrm{~m} \ell$ of sterile Ringer's solution in a sterile jar and shaken on a platform shaker at $220 \mathrm{r} / \mathrm{min}$ for $1 \mathrm{~h}$. Aliquots of the water were originally analysed for total coliforms and E. coli using Merck Chromocult medium, for faecal enterococci using Slanetz and Bartley medium and for coliphages using SABS method 221990. Enterobacteriacae, Staphylococcus, Pseudomonas, coliphages and Ascaris were added to the analyses as the project progressed and analysed according to standard methods.

Vegetables for interior analysis were weighed, then washed and sonicated for $5 \mathrm{~min}$ in a $20 \%$ Jik and Tween solution to sterilise the exterior surface. They were then placed in sterile honey jars to which $100 \mathrm{~m} \ell$ of sterile Ringer's solution was added and were macerated using a food blender. Aliquots of this mixture were subjected to the same analyses as samples from the surface of the crops. Gram stains were done on individual isolated colonies for both internal and external analyses, followed by biochemical testing using API kits. Samples of the same vegetable types were obtained from local supermarkets and from a market and put through the same analytical procedures. Samples of the greywater and of the soil irrigated with greywater were analysed at the start and end of the first stage of the project.

\section{Results}

Average values of the chemical and microbiological analyses performed on the tap water, greywater and hydroponics solution at the start of the project are given below.

The nitrate levels were surprisingly low, but as they were accompanied by high ammonia levels, some reduction of nitrate to nitrite and then ammonia had probably already begun. The amount of time spent in storage tanks before use in the irrigation system is therefore important. Chloride levels were also markedly higher in the greywater than in either the tap water or the hydroponic solution. This could be expected to have an adverse effect on growth in the long term as soils might become salinised. The

\begin{tabular}{|l|c|c|c|c|}
\hline \multicolumn{5}{|c|}{ TABLE 1 } \\
\multicolumn{5}{|l|}{ Mean chemical and microbiological analysis of irrigation solutions } \\
\hline Test & Unit & Tap water & Greywater & Hydroponic \\
\hline Alkalinity & $\mathrm{mg} / \ell \mathrm{CaCO}$ & 66 & 0 & 29 \\
\hline Ammonia (free) & $\mathrm{mg} / \ell \mathrm{N}$ & $<0.50$ & 157 & 32 \\
\hline Boron & $\mathrm{mg} / \ell$ & $<0.25$ & 3.4 & 0.5 \\
\hline Cadmium & $\mathrm{mg} / \ell$ & $<0.05$ & $<0.05$ & $<0.05$ \\
\hline Calcium & $\mathrm{mg} / \ell$ & 16 & 7.5 & 115 \\
\hline Chloride & $\mathrm{mg} / \ell$ & 35 & 220 & 12 \\
\hline Chrome & $\mathrm{mg} / \ell$ & $<0.10$ & 0.14 & 0.1 \\
\hline Conductivity & $\mathrm{mS} / \mathrm{m}$ & 30 & 267 & 223 \\
\hline Copper & $\mathrm{mg} / \ell$ & $<0.10$ & 0.1 & $<0.10$ \\
\hline Lead & $\mathrm{mg} / \ell$ & $<0.05$ & $<0.05$ & 0.05 \\
\hline Magnesium & $\mathrm{mg} / \ell$ & 7.5 & 7.1 & 51 \\
\hline Nickel & $\mathrm{mg} / \ell$ & $<0.10$ & $<0.10$ & $<0.10$ \\
\hline Nitrate + nitrite & $\mathrm{mg} / \ell \mathrm{N}$ & 0.91 & $<0.1$ & 88 \\
\hline Ortho phosphate & $\mathrm{mg} / \ell \mathrm{P}$ & 0.02 & 40 & 38 \\
\hline pH & & 7.4 & 8.1 & 6.3 \\
\hline Potassium & $\mathrm{mg} / \ell$ & 3.6 & 31 & 250 \\
\hline Selenium & $\mathrm{mg} / \ell$ & $<0.05$ & $<0.05$ & 0.08 \\
\hline Sulphate & $\mathrm{mg} / \ell$ & 15 & 137 & 576 \\
\hline TKN & $\mathrm{mg} / \ell \mathrm{N}$ & $<0.50$ & 206 & 37 \\
\hline Total nitrogen & $\mathrm{mg} / \ell \mathrm{N}$ & 0.84 & 206 & 125 \\
\hline Total phosphate & $\mathrm{mg} / \ell \mathrm{P}$ & 0.05 & 69 & 49 \\
\hline$E$. coli & $\mathrm{CFU} / 100 \mathrm{~m} \ell$ & 0 & 35 & 0 \\
\hline Enterococcus & $\mathrm{CFU} / 100 \mathrm{~m} \ell$ & 0 & $>999$ & 0 \\
\hline Phage & $\mathrm{pfu} / 100 \mathrm{~m} \ell$ & 0 & 0 & 0 \\
\hline Staphylococcus & $\mathrm{CFU} / 100 \mathrm{~m} \ell$ & 0 & 0 & 0 \\
\hline T. coli & $\mathrm{CFU} / 100 \mathrm{~m} \ell$ & 0 & 400000000 & 0 \\
\hline
\end{tabular}




\begin{tabular}{|c|c|c|c|c|c|c|c|c|}
\hline \multicolumn{9}{|c|}{$\begin{array}{c}\text { TABLE } 2 \\
\text { Statistical significance of microbiological results from vegetables }\end{array}$} \\
\hline & \multicolumn{4}{|c|}{ External } & \multicolumn{4}{|c|}{ Internal } \\
\hline & $\begin{array}{l}E . \\
\text { coli }\end{array}$ & Entero & Staph & Coliform & $\begin{array}{c}E . \\
\text { coli }\end{array}$ & Entero & Staph & Coliform \\
\hline Carrots & & ND & \begin{tabular}{|c|} 
Tap irrigated \\
sample signifi- \\
cantly higher \\
\end{tabular} & ND & All 0 & All 0 & ND & $\begin{array}{l}\text { Tap irrigated } \\
\text { sample signifi- } \\
\text { cantly lower }\end{array}$ \\
\hline Spinach & ND & ND & ND & $\begin{array}{l}\text { Tap irrigated } \\
\text { sample signifi- } \\
\text { cantly lower }\end{array}$ & All 0 & $\begin{array}{l}\text { Tap irrigated } \\
\text { sample signifi- } \\
\text { cantly lower }\end{array}$ & $\begin{array}{l}\text { Hydropon- } \\
\text { icsolution } \\
\text { significantly } \\
\text { higher } \\
\end{array}$ & $\begin{array}{l}\text { Tap irrigated } \\
\text { sample signifi- } \\
\text { cantly lower }\end{array}$ \\
\hline Madumbe & ND & $\begin{array}{l}\text { Tap irrigated } \\
\text { sample signifi- } \\
\text { cantly lower }\end{array}$ & \begin{tabular}{|c|} 
Greywater \\
irrigated sam- \\
ples signifi- \\
cantly higher
\end{tabular} & $\begin{array}{c}\text { Hydroponic } \\
\text { solution irrigated } \\
\text { samples signifi- } \\
\text { cantly lower }\end{array}$ & All 0 & All 0 & $\begin{array}{l}\text { Greywater } \\
\text { irrigated sam- } \\
\text { ples signifi- } \\
\text { cantly higher }\end{array}$ & ND \\
\hline Peppers & All 0 & All 0 & $\begin{array}{c}\text { Greywater } \\
\text { irrigated sam- } \\
\text { ples signifi- } \\
\text { cantly higher }\end{array}$ & ND & All 0 & $\begin{array}{l}\text { All trial samples } \\
0 . \text { Purchased } \\
\text { samples signifi- } \\
\text { cantly higher }\end{array}$ & ND & ND \\
\hline Beetroot & All 0 & $\begin{array}{l}\text { Greywater } \\
\text { irrigated sam- } \\
\text { ples signifi- } \\
\text { cantly higher }\end{array}$ & $\begin{array}{c}\text { Greywater } \\
\text { irrigated sam- } \\
\text { ples signifi- } \\
\text { cantly higher }\end{array}$ & ND & All 0 & ND & ND & ND \\
\hline Onions & All 0 & ND & $\begin{array}{c}\text { Greywater } \\
\text { irrigated sam- } \\
\text { ples signifi- } \\
\text { cantly higher }\end{array}$ & ND & All 0 & All 0 & All 0 & ND \\
\hline
\end{tabular}

$N D=$ no statistical difference in the results from each of the treatments.

phosphate levels were also high which indicated a potential risk of eutrophication of any water body into which the greywater might seep unless the nitrogen present was utilised. Boron levels were also high, which could result in toxicity to plants. Microbiologically, Enterococcus levels were markedly higher in the greywater than in either of the other solutions. This may be partially owing to the ability of this organism to survive for longer in the environment and also its ability to tolerate a more saline environment. The total coliforms were orders of magnitude higher in the greywater than in either of the irrigation controls. The soil used for potting was tested microbiologically at the start of the trial and was found to contain a high level of total coliforms but very low or non-detectable levels of the other organisms selected.

Control vegetable samples were purchased from commercial outlets targeting the high, middle and low sections of the economic market. These were treated in the same way as the samples grown in the experimental plot. All microbiological results were log-transformed before being analysed using ANOVA. The results obtained are presented in Table 2.

No coliphage or Ascaris ova were detected in any of the samples analysed.

As was expected, the coliform load was the highest in all the vegetables and madumbes showed the highest loading on their exterior. This is possibly because of the roughness of the external skin which provides and ideal niche for bacterial growth. It was unexpected to find relatively high levels of micro-organisms in the interior of the vegetables. This could have been due to insufficient disinfection of the exterior surface before homogenisation or to genuine uptake of organisms. This could not be clarified at this stage of the experiment but will be investigated as the project progresses.

\section{Discussion}

Of the vegetables examined, carrots, spinach, onions and peppers are frequently eaten raw. The risk to humans is therefore highest for consumption of these vegetables. In a first world environment, these vegetables would be thoroughly washed first, but in economically impoverished households, water for washing is scarce and the final result might not be as good as it should be. Onions and carrots are both usually peeled before eating, so the risk for these is reduced and only the internal contamination would be effective. The risk analysis has been worked using the Enterococcus and Staphylococcus results for each of the four vegetables mentioned and using a probability of infection per ingested organism of 0.00001 which is an overall estimated value for bacteria (Schertenlieb, 2005). In each case it was estimated that $100 \mathrm{~g}$ wet weight of the vegetable might be eaten raw on average once a week. These would give a worst case scenario as no pathogen is likely to be present at as high a level as either of the selected micro-organisms. The calculations are shown in Tables 3 to 9 .

When the risks for the various treatments were compared using the ANOVA analysis, it was found that there was no significant difference between the treatments. Use of the greywater irrigated vegetable would therefore not appear likely to cause any additional disease within the community. Further work will be done to clarify the issue of organisms detected inside the vegetables and identify some of the numerous coliforms. Some estimate of actual pathogens may also need to be addressed. At this stage of the project it would appear that the reuse of greywater for the irrigation of vegetables would be of benefit to communities both nutritionally and economically. Environmental effects will however also need to be considered. 
TABLE 3

Estimation of risk in relation to Enterococci on carrots

\begin{tabular}{|l|c|c|c|c|} 
& Greywater & Hydroponic & TAP & Bought vegetable \\
\hline Concentration of organisms per gram of vegetable (mean) & 9 & 1 & 1 & 1 \\
\hline Mass ingested per day (dry mass) & 35 & 35 & 35 & 35 \\
\hline Number of days ingested per year (mean) & 52 & 52 & 52 & 52 \\
\hline Probability of infection & 0.00001 & 0.00001 & 0.00001 & 0.00001 \\
\hline Probability of illness & 0.49 & 0.49 & 0.49 & 0.49 \\
\hline Estimated annual risk of illness & 0.08 & 0.009 & 0.009 & 0.009 \\
\hline
\end{tabular}

\begin{tabular}{|c|c|c|c|c|}
\hline \multicolumn{5}{|c|}{$\begin{array}{c}\text { TABLE } 4 \\
\text { Estimation of risk in relation to Staphylococcus on carrots }\end{array}$} \\
\hline & Greywater & Hydroponic & TAP & Bought vegetable \\
\hline Concentration of organisms per gram of vegetable (mean) & 1 & 2 & 2 & 1 \\
\hline Mass ingested per day & 35 & 35 & 35 & 35 \\
\hline Number of days ingested per year (mean) & 52 & 52 & 52 & 52 \\
\hline Probability of infection & 0.00001 & 0.00001 & 0.00001 & 0.00001 \\
\hline Probability of illness & 0.49 & 0.49 & 0.49 & 0.49 \\
\hline Estimated annual risk of illness & 0.009 & 0.018 & 0.018 & 0.009 \\
\hline
\end{tabular}

\begin{tabular}{|l|c|c|c|c|}
\hline \multicolumn{5}{|c|}{ TABLE 5A } \\
Estimation of risk in relation to Enterococcus on peppers \\
\hline & Greywater & Hydroponic & TAP & Bought vegetable \\
\hline Concentration of organisms per gram of vegetable (mean) & 5 & 1 & 1 & 1 \\
\hline Mass ingested per day & 27.6 & 27.6 & 27.6 & 27.6 \\
\hline Number of days ingested per year (mean) & 52 & 52 & 52 & 52 \\
\hline Probability of infection & 0.00001 & 0.00001 & 0.00001 & 0.00001 \\
\hline Probability of illness & 0.49 & 0.49 & 0.49 & 0.49 \\
\hline Estimated annual risk of illness & 0.035 & 0.007 & 0.007 & 0.007 \\
\hline
\end{tabular}

\begin{tabular}{|l|c|c|c|c|}
\hline \multicolumn{4}{|c|}{ TABLE 5B } \\
Estimation of risk in relation to Staphylococcus on peppers \\
\hline & Greywater & Hydroponic & TAP & Bought vegetable \\
\hline Concentration of organisms per gram of vegetable (mean) & 4 & 2 & 2 & 1 \\
\hline Mass ingested per day & 27.6 & 27.6 & 27.6 & 27.6 \\
\hline Number of days ingested per year (mean) & 52 & 52 & 52 & 52 \\
\hline Probability of infection & 0.00001 & 0.00001 & 0.00001 & 0.00001 \\
\hline Probability of illness & 0.49 & 0.49 & 0.49 & 0.49 \\
\hline Estimated annual risk of illness & 0.028 & 0.014 & 0.014 & 0.014 \\
\hline
\end{tabular}

\begin{tabular}{|l|c|c|c|c|}
\hline \multicolumn{7}{|c|}{ TABLE 6 } \\
Estimation of risk in relation to Enterococci on onions \\
\hline & Greywater & Hydroponic & TAP & Bought vegetable \\
\hline Concentration of organisms per gram of vegetable (mean) & 16 & 1 & 1 & 1 \\
\hline Mass ingested per day & 28.64 & 28.64 & 28.64 & 28.64 \\
\hline Number of days ingested per year (mean) & 52 & 52 & 52 & 52 \\
\hline Probability of infection & 0.00001 & 0.00001 & 0.00001 & 0.00001 \\
\hline Probability of illness & 0.49 & 0.49 & 0.49 & 0.49 \\
\hline Estimated annual risk of illness & 0.117 & 0.0073 & 0.0073 & 0.0073 \\
\hline
\end{tabular}




\begin{tabular}{|l|c|c|c|c|}
\hline \multicolumn{5}{|c|}{ TABLE 7 } \\
\multicolumn{1}{|c|}{ Estimation of risk in relation to Staphylococcus on onions } \\
\hline & Greywater & Hydroponic & TAP & Bought vegetable \\
\hline Concentration of organisms per gram of vegetable (mean) & 1 & 16 & 1 & 2 \\
\hline Mass ingested per day & 28.64 & 28.64 & 28.64 & 28.64 \\
\hline Number of days ingested per year (mean) & 52 & 52 & 52 & 52 \\
\hline Probability of infection & 0.00001 & 0.00001 & 0.00001 & 0.00001 \\
\hline Probability of illness & 0.49 & 0.49 & 0.49 & 0.49 \\
\hline Estimated annual risk of illness & 0.0073 & 0.117 & 0.0073 & 0.014 \\
\hline
\end{tabular}

\section{TABLE 8}

\section{Estimation of risk in relation to Enterococci on spinach}

\begin{tabular}{|l|c|c|c|c|}
\hline & Greywater & Hydroponic & TAP & Bought vegetable \\
\hline Concentration of organisms per gram of vegetable (mean) & 3 & 1 & 2 & 1 \\
\hline Mass ingested per day & 14.02 & 14.02 & 14.02 & 14.02 \\
\hline Number of days ingested per year (mean) & 52 & 52 & 52 & 52 \\
\hline Probability of infection & 0.00001 & 0.00001 & 0.00001 & 0.00001 \\
\hline Probability of illness & 0.49 & 0.49 & 0.49 & 0.49 \\
\hline Estimated annual risk of illness & 0.011 & 0.0036 & 0.0071 & 0.0036 \\
\hline
\end{tabular}

\begin{tabular}{|l|c|c|c|c|}
\hline \multicolumn{5}{|c|}{ TABLE 9 } \\
\multicolumn{1}{|l|}{ Estimation of risk in relation to Staphylococcus on spinach } \\
\hline & Greywater & Hydroponic & TAP & Bought vegetable \\
\hline Concentration of organisms per gram of vegetable (mean) & 3 & 1 & 2 & 2 \\
\hline Mass ingested per day & 14.02 & 14.02 & 14.02 & 14.02 \\
\hline Number of days ingested per year (mean) & 52 & 52 & 52 & 52 \\
\hline Probability of infection & 0.00001 & 0.00001 & 0.00001 & 0.00001 \\
\hline Probability of illness & 0.49 & 0.49 & 0.49 & 0.49 \\
\hline Estimated annual risk of illness & 0.011 & 0.0036 & 0.0071 & 0.0071 \\
\hline
\end{tabular}

\section{References}

HURST CJ (2002) Estimating the risk of infectious disease associated with pathogens in water. In: Hurst CJ, Crawford RL, Knudson GR, McInerney MJ and Stetzenbach LD (eds.) Manual of Environmental Microbiology. (2 $2^{\text {nd }}$ edn.) 309-319. ASM Press, Washington, DC.

SCHERTENLIEB R (2005) From conventional to advanced environmental sanitation. Water Sci. Technol. 51 (10) 7-14. 